\title{
Methodological procedures for the interpretation of images present in tactile illustrated books
}

\author{
Elizabeth Romani, \\ Clice de Toledo Sanjar Mazzilli
}

\section{INTRODUCTION}

The volume of book production with braille text in Brazil has increased significantly in the last few years. Nonetheless, the data collected point to a context still lacking in mechanisms that allow access to them, considering the population with visual impairment. According to the latest demographic census by the Brazilian Institute of Geography and Statistics (IBGE), in 2010, around 45.6 million Brazilians, which amount to $23.9 \%$ of the population, presented some sort of incapacity or impairment. Among them, almost 530 thousand declared themselves blind and 6 million, with great seeing difficulties. Of the total, $5 \%$ were children, $10 \%$ young people, $48 \%$ adults and $37 \%$ elderly.

In face of the panorama of visual impairment in Brazil, we recognized the relevance of the production of this kind of publication and identified the lack of books adapted to haptic reading ${ }^{1}$ destined for children at the alphabetization stage. The Dorina Norwill Foundation for the Blind (FDNC, in the Portuguese acronym) classifies the literary distribution in three accessible formats: braille with enlarged text (braille and ink), spoken (audiobook) or accessible digital (Daisy). A large portion of the contemporary book production targeted at people with impairments is found in the format of audiobooks. According to data at FDNC website (2012), half of the titles available in the foundation's collection is in audio format, amounting to 886 works in Braille against 1.569 in audio. The use of voice softwares and the internet has opened up new access routes to knowledge; however, these tools are destined mainly to blind adults, who, many times, haven't been alphabetized in Braille. It is undeniable that technological advances have allowed an increase of the collection; however, this investigation

1 The term "haptic", according to Polato (2010), is used to highlight active touching, in which touch is accompanied by the movement of the hand, the wrist, the arms, the back, a tactile sensation emphasized on the skin, the musculature and the tendons. 
focuses on printed books in braille with tactile images (tactile illustrated books). Materiality, for the developing reader, blind or not, is fundamental in the process of apprehension of knowledge and for the development of the perceptible field. Tactile communication, defended by Munari (1985), teaches the child a new way to read information.

A tactile illustrated book is a product that demands technical care because, besides the text in braille, also includes images in relief, which is what makes it scarcely available in the national and international publishing market. Printing in braille is still a barrier in the publishing sector due to the specificities in reproduction and editing, so few publishers invest in this segment, leaving the production of such titles in the hands of private initiatives or non-governmental organizations. This production is also tied to the charitable character of aid institutions for people with impairments, which motivates low cost as a basic project premise. When it comes to books with tactile images, the complexity of the editorial project increases because, besides the technique of reproduction, the conception of the design will affect the comprehension of the image by the blind.

In Brazil, the two main institutions that produce books with braille text and nationwide circulation are the Dorina Norwill Foundation for the Blind (FDNC), formerly the The Brazilian Foundation of the Book for the Blind, in São Paulo, and the Benjamin Constant Institute (IBC), formerly the Imperial Institute for Blind Boys, in Rio de Janeiro. Both institutions distribute books to schools, associations, libraries and organizations all over the country, which has been confirmed during field visits. Besides the Braille Press, these institutions provide services of adaptation and transcription of textbooks financed by the government and perform services of adaptation in dotted relief for publishers. Despite the efficiency of production, resulting in high print runs, their printing process is somewhat restrictive, which results in a limitation of the haptic perception of blind readers.

Although the offer of tactile books has increased due to the advancement of printing technologies, there is still a lack of instruments to analyse the efficiency of this kind of book, considered as a publishing product, in transmitting information. Hatwell (2010) explains that the process of tactile recognition demands a lot of time and effort by blind readers, because haptic perception is fragmented in moments of appreciation, requiring much concentration during the exploration process. The author still reports that haptic reading requires an effort of memory and synthesis to interpret the unitary representation of the object, concluding that it's very difficult to conduct research with people with visual impairment because there are many variables to analyse, one of them the learning delay in reading and writing braille. 
The bibliographic review showed that the theories on haptic perception weren't enough to elucidate the level of clarity of blind readers in relation to tactile images, because the studies, such as the ones by Amiralian (1997), Bonanomi (2010), Hatwell (2010) and Secchi (2011), focus on the cognitive psychology of the blind or their processes of mental construction. Other than the researches on perception, the authors Bruno (1997), Duarte (2011), Reily (2004) and Restelli (2002) approach the teaching of drawing to blind children, rather than observing their comprehension during reading. Therefore, the absence of this kind of study, especially in the field of graphic design, motivated the development of an empirical research on the comprehension of images by the blind in the case of tactile illustrated books.

The premise was that the text in braille would be legible when well done, and that many of the ways of representing images found in tactile books weren't understood by blind readers. Consequently, reading would have to be aided by a mediator: parents, friends, neighbors or, what would happen more frequently, by the meaning of the words in the text. With that in mind, we considered that the reading of publications jointly selected with the target audience - blind children and adults - would contribute to the comprehension of the haptic reading process based on certain tools and procedures created specifically for this type of reader. Therefore, the aim of this paper is to present the methodological steps used to assess the perception of blind readers, bearing in mind the process of image creation in the context of the design of tactile illustrated books.

\section{METHOLOGICAL PROCEDURES PROPOSED FOR ANALYSIS}

The methodological steps undertaken in the research were the following: selection of the object of study, analysis of the chosen book, translation of texts in other languages into Portuguese, preparation of research protocols, definition of the dynamic for the reading encounters and, finally, data collection. Bauer and Gaskell (2012), Cardeal (2011) and Vianna (2003) provided the basis for the instruments and procedures of the analysis.

\section{Selection of the books}

The analysis of blind readers' understanding of tactile illustrated books was based on instruments and procedures of qualitative research, combining different sources of information. The first step, prior to the analysis proper, was assessing the various initiatives of tactile illustrated book production and identifying their graphic proposals. Currently, a good portion of the graphic development of tactile books is linked to the areas of knowledge of pedagogy and psychology, and is 
developed in the centers of assistance to people with visual impairment. For this reason, in Brazil, the books of different publishing initiatives are similar and reproduced based on the conception of didactic material for the blind. From 2012 to 2015 , a survey of the tactile publishing production in the city of São Paulo was performed, after visits to its three major braille collections: the Braille Section of the Senac SP Library, the São Paulo Library and the Louis Braille Library (BLB).

The collections found in the libraries weren't very different from one another, being mostly composed of braille books produced by the FDNC or by the IBC. There was the occasional book by other publishers, such as Paulinas, WG Produto and Pallas, and handcrafted titles by the BLB. The only books not printed or adapted by the FDNC were those of the Adélia collection, O livro negro das cores, the Traça Traço series and the handcrafted books. After building a panorama of tactile illustrated books in the city of São Paulo, we observed that the graphic and tactile solutions were not very different, with exception of the books produced without any interference by the FDNC.

The field research was essential for the assessment of the collection of tactile illustrated books available as potential objects of study. Based on this, it was possible to choose a research focus, selecting the following titles for the reading evaluation: O Chapeuzinho Vermelho, by Bia Villela; Abraço de urso, by Cláudia Cotes; Adélia sonhadora, by Lia Zatz; Ruvidino in piscina, by the Istituto dei Ciechi di Milano; Des vers de travers, by Anette Diesen; and Petit souffle de vent, by Elisa Lodolo. Furthermore, the choice of these books hinged on the purpose of the research: to investigate image comprehension. In this manner, the selection of the books should represent the diversity of the Brazilian and, in some cases, foreign production, as well as different elaboration methods and graphic languages.

\section{Preliminary analysis of the selected books}

After selecting the titles, each book was analysed with the goal of broadening the discussion of the theoretical field based on the products available in the market. This moment of investigation was destined for the photographic register of the double pages, identification of the details of the object of study and comprehension of the narrative proposal regarding the graphic elements present in the book. In this way, during the readings, it was possible to observe whether the participants would recognize such differentiated aspects in each of the selected proposals. The preliminary study also allowed the assimilation of the data obtained in the bibliographical review, in the attempt to establish a link to the theory. The method adopted in the analysis of the books was composed of different approaches, one of them the analysis of the criteria of the graphic language present in these artefacts. The central purpose of this construction of knowledge was 
understanding the relation between text and image in tactile illustrated books, thus confirming the role of the word as reading mediator for the illustration.

The studies by Barthes (1990) were a reference for the analysis between text and image, although this production derives from the analysis of advertising pieces. The author argues that, since the invention of books, the relation between text and image is present in publications. Image can duplicate the information of the text through a phenomenon called redundancy or is able to provide new information to the understood text or even add new relations, in what is called complementarity. These concepts were taken up by Van der Linden (2011) in the analysis of illustrated tactile books. While aware of the differences, we appropriated his terms for the methods of message analysis: [1] linguistic messages: texts that appear alongside the graphic composition. The author believes that this message is present in all images in the shape of subtitle, labels and descriptions. The text may be interpreted based on the denotation and connotation of its meanings. [2] Iconic messages: an image may be codified, transmitting a denoted message or a non-codified one (based on anthropological knowledge), in which the symbolic messages is connoted.

Barthes (1990) presumes that image is representation, formed by a series of signs that, when interpreted, generate a piece of information. The analysis of the iconic message took into consideration the study on visual perception by Arnheim (2004) and the information collected in the reading encounters, using the systematized data and the observation of the participants during the process of reading the tactile images. The complementation of the information made it possible to compare the visual perception with the haptic perception.

The linguistic message followed the classification of Nikolajeva and Scott (2011), namely: narrative (with story) and non-narrative (with poetry, a dictionary, a fictional text), excluding traditional short stories from this classification, since they don't need illustration to transmit their message. The iconic message was analysed, with more emphasis, through the descriptions of visual perception by Arnheim (2004) and Bonanomi (2004), combining occasional comments collected in the reading encounters. In the composition of the image, the contour lines, the material used and the details were observed, as well as the way each reader appropriated the materiality present in the books to conclude what was the meaning in the illustrations.

Other than the linguistic message and the iconic message, the study was composed of the analysis of elements of graphic design, addressing the topics: typography and braille; page composition and graphic production. In terms of the graphic, he text composition and the structure of the designed page were analyzed considering both versions for reading, in ink and braille. In this way, we sought to describe the typographic font used in ink, although the identification of the 
version and size were an approximate description, as it was not confirmed with the designers or the publishers.

As regards the page composition, the structure of formatting through the pages was described considering the compositional relation of text and image in the double pages. The text and image composition was classified according to Van der Linden (2011): redundancy, collaboration and disjunction. The definition by Dondis (2003) was also adopted to characterize the anatomy of the message as representational, abstract and symbolic. Despite the appropriation of theories of visual perception and visual communication for grounding the analysis methodology, the relation of the blind with images is not similar to that of people who can see, and the role of image in books for blind readers is still a developing field of study.

In terms of the graphic production, we examined the issues related to the production of tactile illustrated books, which, together with the language of images, will enrich the degree of understanding of haptic reading. Traditional books present some variants of production, based on the choice of support and finish, but tactile books require a careful choice of technique regarding the creation of texture. In each case study, it was described how each volume was produced, considering the use of materials and the techniques employed. The positive and negative aspects of each proposal were analysed according to the theories compiled and the notes by blind readers. Finally, the data were systematized in a summary table so as to facilitate comparison and subsequent analysis.

\begin{tabular}{|l|l|}
\hline Text anatomy & \\
\hline Typography & \\
\hline Alignment & \\
\hline Braille & \\
\hline Message anatomy & \\
\hline Text and image relation & \\
\hline Composition & \\
\hline Format & \\
\hline Support & \\
\hline Reproduction technique of the text in braille & \\
\hline Reproduction technique of the tactile images & \\
\hline Binding & \\
\hline Cover & \\
\hline
\end{tabular}

Table 1: Summary table of the analyzed data 


\section{Reading encounters}

In this research, the meetings with blind readers were called reading encounters, believing this to be the most appropriate name for this stage of data collection. The main purpose of these encounters was identifying the legibility of the elements within the context of the narrative, involving the reading comprehension of the image, the text and the book composition. The supervision of mediated reading is commonly found in projective methodology, with the purpose of understanding the reaction of the user to a stimulating situation (Gil, 2000). Although the researcher participated in the activity, the intention was intervening as little as possible during the reading process, restricting the mediation to occasional stimuli regarding an enigmatic image. The mediation, identifying the image after the text was read, was a strategy adopted so that the reader would gradually learn the language of drawing.

\section{Preparation of the books}

So that there would be a full understanding of the text and in order to observe how much blind readers depend on the text for the comprehension of tactile images, books written in languages other than Portuguese were translated. During the reading, these were delivered to readers in the shape of subtitles in loose sheets (Figure 1) and in the narrative sequence of the original title. The transcription into braille code was executed in a plastic slate, which didn't allow for total legibility, identified by the adult participants, who claimed a slight difference in the dots and more difficulty to get a fluid reading. However, considering that the mass of text was small in all the analysed books, the quality of the braille didn't hinder the development of the research.

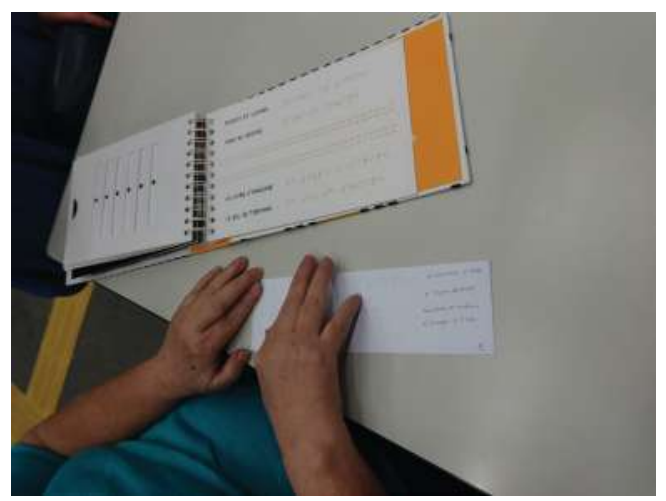

Figure 1: Example of the application of subtitles during the reading of a French title. 


\section{Elaboration of research protocols}

For the reading encounters, the data collection was structured based on methods of qualitative research, especially participant observation and a questionnaire at the end of each book. Bauer and Gaskell (2012) defend, as an alternative to interviews, the observation of the participant in order to obtain more amplitude and depth of information, making it possible to triangulate different impressions and observations. The questionnaire or interview as a source of data limits the information provided by the interviewee. "The real goal of qualitative research is not to tell opinions or people, but rather to explore the spectrum of opinions, the different representations of the matter at hand" (Bauer and Gaskell, 2012: $68)$.

Bearing this in mind, the extraction of the data occurred especially through the observation of the reader with visual impairment during the reading process of a pre-selected book. To avoid losing information, the reading sessions were recorded in audio and video, and some situations were registered with photography. The monitoring of the user's behaviour regarding the book allowed us to add data that could have passed unnoticed during the reading dynamic with the researcher. In addition, the data collection through the questionnaire strengthened and complemented the observation. The construction of the questionnaire obeyed the recommendation of a structured interview (Silverman, 2009), namely, using standard presentations, following a sequence of questions, avoiding explaining the questions, avoiding interruptions and external opinions, never suggesting an answer and not improvising answers during the study.

The readings and questionnaires were applied after a schedule was decided with the agreement of all parts. First there was the collection of personal data, so as to know a little about the participants. The participants' forms (Table 2) with personal information and the developed protocols composed the participant's profile and allowed knowledge of their existing imagetic repertoire or even to understand if the reader retains visual memory. To preserve the participants' identification, fictional names were adopted. Although each participant had a form of their own, the dynamic was mostly conducted in small groups. According to Bauer and Gaskell (2012), in a group environment, people are more willing to accept new ideas and explore their implications. The group might provide levels of involvement that are rarely observed individually. On the other hand, some opinions may prevail over others. 


\begin{tabular}{|l|}
\hline Name \\
\hline Age \\
\hline Type of visual impairment \\
\hline How old were you when you started learning braille? \\
\hline What is your connection to the book? \\
\hline Do you have any knowledge of drawing? \\
\hline
\end{tabular}

Table 2: Script for the profile of the participants.

\section{Site selection and sampling}

After establishing the investigation protocols, the following step was selecting a site with the proper infrastructure to carry out the research, as well as the getting the institutions'consent to conduct the activities at their facilities. The choice of participant institutions followed two criteria: legitimacy and participant access. The encounters occurred in institutions located in the city of São Paulo, due to the feasibility of access, as it was understood that the estimated number of visits would not be feasible in case there was the need for long commutes. In this way, the BLB and the Padre Chico Institute (IPC) were chosen. At the BLB, the research was targeted at adults, given the low frequency of children at the library (during six months of constant visits, no children were seen at the site). After visiting many institutions in the city of São Paulo, the IPC was chosen to conduct the research with the children. The selection of this school for the readings was a result of its historical importance and the fact that there were children there who already had contact with tactile images.

The management of both the institutions that hosted the research chose the group of participants. In each institution, a distinct group of readers was heterogeneously composed: adults between 36 and 64 years of age, congenital and late blind, and a group of children and one teenager between 8 and 18 years of age, who lost sight before the age of 1 , and with no indications of visual memory. At first, the intended sampling was of a higher number of participants, both adult and children, however, the selection was at the hands of the management of both institutions that hosted the research. Due to the complexity of the dynamic with blind people, a typicality sampling was chosen, considering a small group to represent the readers in question.

\section{Dynamic of the encounters}

After the Informed Consent Forms were signed, the group readings were scheduled on a weekly basis. The encounters with the children were overseen by 
the Coordinator of Arts and Music Isabel Bertevelli, and by the music teacher, Marcela Trevisani, within the IPC. All the activities involving data collection with children were overseen by Marcela, always in the afternoon, after the regular school activities. Each encounter lasted 3 hours and took place between October and December 2015. A similar process happened with the group of adults at the BLB. The encounters occurred weekly, in the period from July to December 2015, with previous scheduling of the participants and an average duration of 3 hours. The extensive research period was made possible due to the involvement of all the participants of the group and the management, that supported the research.

The observation of children and adults was aided by video registers during the reading process, properly authorized by the participants. These registers helped analyze body posture, a piece of data that is not transmitted by oral registers. Photographic documentation preserved the identity of the participants insofar as the registers were restricted to hand framing (Figure 2). At the end of the sessions, all the images were sent to their respective institutions, IPC and BLB, in order to obtain the consent for use.

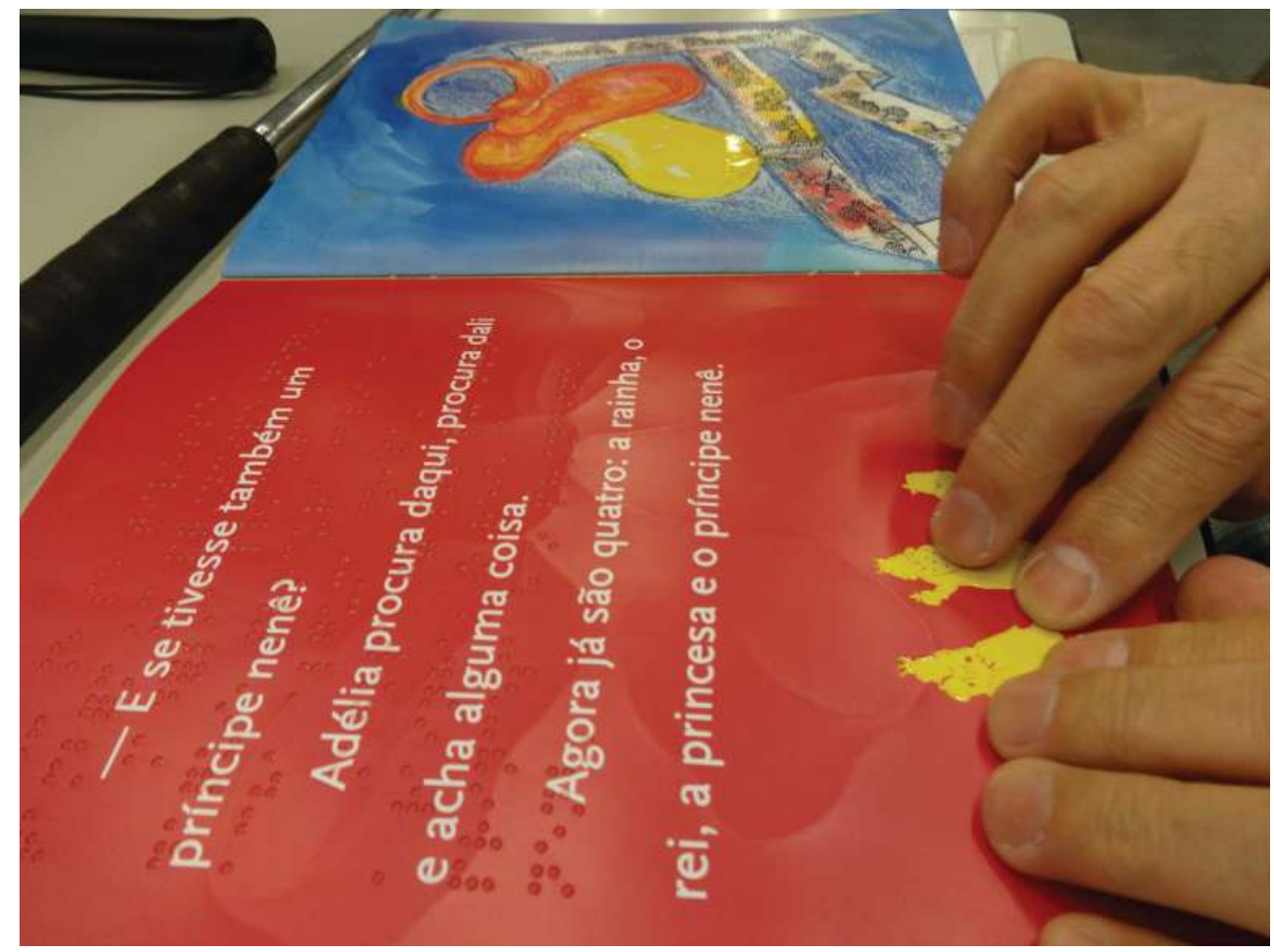

Figure 2: Example of images collected during reading. 
The research was based on voluntary adherence by the participants, and the child or adult could solicit the end of the activity at any moment during the interview, as well as the interruption of the recordings. The conduction of the encounters was important so that the child didn't become too distracted during the reading, ensuring that the activity respected individual time of haptic perception. The researcher assumed an active role, defended by action-research (Vianna 2003), by posing some strategic questions during the contact with the children, that promoted a larger understanding of the reading: "Could you speak about this?", "What else do you understand?", "Why do you think that?", "What do you think this drawing represents?".

At the first reading encounter, the purposes of the activity were explained, emphasizing that the research was targeted at the books. It was hoped that, in this way, the participants would feel they had more freedom to respond, without fearing an institutional school evaluation, especially in the case of the children. After the process was explained, each book was delivered in the participant's hand so that they would have their own perceptions of the tridimensional object. They were not given a specific time to read it. After signaling the end of the reading of each double page, the book was passed on to another participant. At the end of the reading, the questions were asked to each person.

The questionnaire conformed to the following principles of behavior, as Silverman (2009) describes: ask the question exactly as it is written and in the order of the script, without demonstrating surprise or disapproval after the answer, and offer explanations when there are doubts. The performance of the interviewer-mediator had the goal of preventing the conversation from deviating from the matter at hand, in this case, the analyzed books. The replies were registered at the time of the interview through notes and the use of recordings for a final check. The questions were open, and fewer than those of the mediated intervention.

\section{Data collection}

The data analysis began with the participants' reports, collected through a questionnaire (Table 3) and questions mediated during the reading, systematizing the data for each participant. Information was collected regarding each double page of the book, measuring the degree of comprehension of the tactile image through the inquiry: recognizes immediately; recognizes with difficulty; doesn't recognize and believes it to be. In the case of "immediate" recognition, it is considered that the reader doesn't need mediation for understanding the illustration and when there is "difficulty", the reader understands the image after receiving a clue (verbal or textual). Before each encounter, a form was designed for data collection (Table 3), in a similar way to Cardeal (2013). 
child 1 teenager adult

\begin{tabular}{|c|c|c|c|c|c|}
\hline Place in the book & Image & $\begin{array}{l}\text { Recognizes } \\
\text { immediately }\end{array}$ & $\begin{array}{l}\text { Recognizes } \\
\text { with difficulty }\end{array}$ & $\begin{array}{l}\text { Doesn't } \\
\text { recognize }\end{array}$ & $\begin{array}{l}\text { Believes it to be } \\
\text { or recognizes }\end{array}$ \\
\hline Cover & 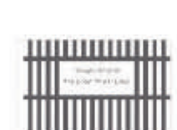 & $\begin{array}{c}\Delta \square \\
00\end{array}$ & ○ & & \\
\hline \multicolumn{6}{|l|}{ Page 2} \\
\hline \multicolumn{6}{|l|}{ Page 4} \\
\hline \multicolumn{6}{|l|}{ Page 5} \\
\hline & i & $\Delta O$ & $\square$ & - & Cloud \\
\hline Page 6 & 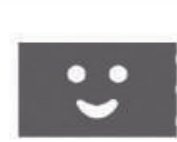 & 100 & 口 & & $\begin{array}{l}\text { Triangle } \\
\text { Book } \\
\text { Comb }\end{array}$ \\
\hline \multicolumn{6}{|l|}{ Page 7} \\
\hline \multicolumn{6}{|l|}{ Page 9} \\
\hline & & 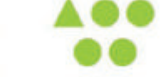 & 口 & & Ladder \\
\hline Page 10 & 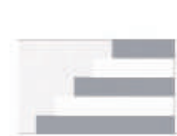 & $\triangle 00$ & 口 & & \\
\hline Page 12 & : & & 0 & 둥 & Smile \\
\hline
\end{tabular}

Table 3: Form for data collection. 


\begin{tabular}{|l|}
\hline PARTICIPANT'S NAME \\
\hline DATE BEGINNING OF THE READING \\
\hline What did you understand about the book? \\
\hline What did you like the most about the book? \\
\hline What didn't you like? \\
\hline How was the reading? \\
\hline What would you say about the reading of the text in braille? \\
\hline What did you understand about the drawings? \\
\hline If you had to exclude one of the drawings, which would it be? Why? \\
\hline Which drawings did you recognize immediately? \\
\hline Why do you think that happened? \\
\hline Would you read this book again? \\
\hline
\end{tabular}

Table 4: Script for data collection of the books.

\section{Difficulties encountered}

The described methodological procedures were put into practice in the second semester of 2015, when the six tactile illustrated books selected were evaluated. In the first month of the research with adult readers, the participants' moment of apprehension was used in order to discuss other types of publication with tactile images. In this period, there was clear rejection of the participants in relation to this kind of image. This refusal was later understood as lack of confidence, given they were from a generation that didn't have contact with drawing and images in the process of braille alphabetization. The difficulty of reading tactile illustrations became clear throughout the encounters. At first, the participants appeared reticent to say what they read in the illustrated pages, because they believed it was a matter of personal inability instead of imagining that the book could present some problem of representation. At the first encounter, the 64-year-old participant said: "I'm very bad at reading diagrams". This was another conflict to be overcome: the understanding that tactile images go beyond the diagrams of teaching resources.

After breaking down all the barriers that could interfere in the process of haptic reading, an assiduous encounter group was established. The research project predicted individual reading sessions, however, we opted to conduct group dynamics, as the participants were willing to collaborate at all times. Although unforeseen, the conversations held among the participants during the encounters also proved themselves sources of information. 
At the same time that the encounters at BLB began, the IPC was contacted for the conduction of a similar research with the children. Encounters were scheduled outside of school hours, after lunch and before parents came for their children, between 1 and 3 in the afternoon. This slot was the first barrier, because, in this period, the children had extracurricular activities, such as music, vocational guidance and dance. The management was asked to select children fluent in braille reading and that were willing to participate of their own free will. Due to the fact that the activity would compete with these classes and that the research was voluntary, few children were interested in participating, especially since it was an activity related to reading. For the first two books, we had a group of four children between 8 and 10 years of age, three boys and one girl. However, of this initial group, only the 8-year-old girl was interested in continuing to participate in all encounters.

The absence of interest in the reading sessions was a factor not envisioned in the research project. After this initial impasse, the Arts coordinator at the school suggested the substitution of the boys by an 18 -year-old girl. This student was a later learner of braille, and consequently behind in school, but very interested in reading. Unlike what happened with the adult participants, where there was the need for previous interaction so that they could feel more confident, the IPC students didn't have any problem of inhibition or socialization. The impasse faced was of a different nature: making them focus on the book, which required a reevaluation of the initial composition with four children simultaneously.

Another point of divergence between adults and children, and that was also not predicted in the project, was the questionnaire presented after the reading. Only the teenager had the patience to take it seriously and answer the questions calmly, unlike the girl who didn't do it, so the questionnaire was excluded from the encounter with the children, proving to be an inappropriate instrument for the task.

\section{CONCLUDING REMARKS}

Investigating the production of tactile images was the guiding principle of this research, to question whether tactile illustrations, in the current context of the production of tactile illustrated books in Brazil, were understood by blind readers, ensuring them autonomy in reading. At first, a bibliographic review was conducted to obtain the instruments of analysis, however, the isolated theories proved to be insufficient to answer every inquiry, but served to establish comparative parameters to discuss the books selected for case study. The preliminary analysis of the selected books allowed us to understand the narrative proposed by each title, and the systematized data were important to confront the theoretical 
basis with the practice of reading. Considering that not every study of visual perception applies to haptic reading, research with the blind indicated some of the artifices used by them to interpret tactile images.

The interaction with blind children and adults allowed an approximation with the reader, something that would not have been possible merely through the literature. A dialogue was therefore established beyond the book, making it possible to understand their perceptible universe. Blind readers, before anything, are people who express themselves at every moment, share emotions during reading, and all the feelings were constantly reflected in the visible comfort with which children arrived for the reading activity and the anxiety shown by the adults with each new title and discovery. The moment of reading was always accompanied by much talk and grimaces by the participants, for they were sometimes taken by surprise by the images.

When assembling different reading groups, there wasn't the intention of establishing comparative patterns between the comprehension level of the adults and the children. However, during the activities, some differences became clear, particularly in the confidence found in the children, unlike the suspicion of the adults, not only in the process of reading, but also in opening up to dialogue in the first encounters. The adults who participated were late blind, so they sought a parallel between the information read and visual memory, which not always permitted a clear interpretation of the visual message. The children, on the other hand, were building a graphic repertoire at school, through readings and during arts classes.

The methodological trajectory described in this article had no intention of closing the subject, rather to broaden the discussion on possible methods of data collection with the participation of blind readers. By considering the limited discussion available in the field of haptic reading of illustrated books, the studied procedures allowed us to confront the knowledge postulated in some educational institutions, as well as those that offer aid to individuals with visual impairment.

\section{ACKNOWLEDGMENTS}

To CAPES for the financial support to the research and support during the PDSE program.

\section{REFERENCES}

Amiralian, M. L. T. M. 1997. Compreendendo o cego: uma visão psicanalítica da cegueira por meio de desenhos-estórias. São Paulo: Casa do Psicólogo.

Arnheim, R. 2004. Arte e percepção visual: uma psicologia da visão criadora: nova ver- 
são. Trans. Ivone Terezinha de Faria. São Paulo: Pioneira Thomson Learning.

Bauer, M. W. and Gaskell, G. (Orgs.). 2012. Pesquisa qualitativa com texto, imagem e som: um manual prático. Trans, Pedrinho Guareschi. 13 ed. Rio de Janeiro: Vozes.

Barthes, R. 1990. A retórica da imagem. In: O óbvio e obtuso: ensaios críticos III. Trans. Léa Novaes. Rio de Janeiro: Nova Fronteira. p. 27-43.

Bonanomi, P. 2004. Costruire il piacere della lettura. In: Quatraro, A (Org.). Immagini da toccare: proposte metodologiche per la realizzazione e fruizione di illustrazioni tattili. Monza: Biblioteca Italiana per i Ciechi “Regina Margherita” ONLUS.

Bruno, M. M. G. 1997. Deficiência visual: reflexões sobre a prática pedagógica. São Paulo: Laramara,

Cardeal, M. 2011. Metáforas visuais - redundâncias táteis. In: Duarte, M. L. B.; Piekas, M. I. (Orgs.). Desenho infantil em pesquisa: imagens visuais e táteis. Curitiba: Editora Insignt.

Censo Ddemográfico. 2010. Características gerais da população, religião e pessoas com deficiência. In: IBGE. <www.geoftp.ibge.gov.br/regioes_de_influencia_das_cidades/>.

Dondis, D. A. 1997. Sintaxe da linguagem visual. Trans. Jefferson Luiz Carmargo. São Paulo: Martins Fontes. (Coleção a).

Fundação Dorina Nowill para Cegos. 2012. Relatório Anual. São Paulo, s.d. In: <http:// fundacaodorina.org.br/quem-somos/resultados/>.

Gil, A. C. 1999. Métodos e técnicas de pesquisa social. 5 ed. São Paulo: Atlas.

Hatwell, Y. 2010. Psicologia cognitiva della cecità precoce. Trans. Michelina Mosca Di Dino. Monza: Biblioteca Italiana dei Ciechi Regina Margherita.

Nikolajeva, M., SCOTT, C. 2011. Livro ilustrado: palavras e imagens. Trans. Cid Knipel. São Paulo: Cosac Naify,

Munari, B. 1985. I laboratori tattili: a cura di Bruno Munari. Itália: Zanichelli.

Reily, L. 2004. Escola inclusiva: Linguagem e mediação. Campinas: Papirus.

Restelli, B. 2002. Giocare con tatto: per una educazione plurisensoriale secondo il método Bruno Munari. Milan: FrancoAngeli.

Sescchi, L. 2011. Toccare la pittura: percezione, cognizione ed interiorizzazione di forma e contenuto, attraverso l'educazione estetica dedicata alle persone non vedenti ed ipovedenti. In: Associazione Amici dell'Accademia Carrara Onlus (Org.). L'arte vista sotto un'altra ottica. Roma: Armando Editore. p. 67-86.

Silverman, D. 2009. Interpretação de dados qualitativos: métodos para análise de entrevistas, textos e interações. Trans. Madga França Lopes. Porto Alegre: Artmed.

Van der Linden, S. 2011. Para ler o livro ilustrado. São Paulo: Cosac Naify.

Vianna, H. M. 2003. Pesquisa em Educação: a observação. Brasília: Plano Editora. 